\title{
Demand and Strategy of Imports in Declining Foreign Exchange Reserves
}

\begin{abstract}
Submitted 11/03/20, 1st revision 14/04/20, 2nd revision 05/05/20, accepted 20/07/20
\section{Sri Indah Nikensari ${ }^{1}$, NFD Puspitasari ${ }^{2}$, Amin Pujiati $^{3}$}

Abstract:

Purpose: The purpose of this study is to propose alternative ideas of import strategy related to the needs of imports to increase economic growth, compare with the availability of foreign exchange reserves.

Design/Methodology/Appoach: This paper proposes possible alternative ideas for import strategies, after examining what factors influence imports. Policies at the international and regional levels are considered in formulating simple ideas for solving problems. Document analysis, as a form of qualitative research, is also used in this study. To answer the question, data from ASEAN countries in the 2012-2018 period were used, which were analyzed using panel data regression equations.

Findings: We found that GDP and foreign exchange reserves (FER) have the highest influence on import demand compared to other variables, but the significance of FER is greater than of GDP. Because there is a downward trend in FER in several ASEAN countries, the paper proposes the use of a protective import strategy consisting of a strategy of cooperation (negotiation and renegotiation) and non-cooperation (unilateral decision) to maintain sustainable imports.

Practical Implications: The decline in FER will have an impact on the country's ability to import. Protective strategies, both through cooperation and non-cooperation, can reduce the current account deficit. The protective strategy will also grow the domestic economy, starting from the growth of the domestic industry, reducing unemployment, increasing people's income.
\end{abstract}

Keywords: Imports demand, GDP, forex reserve, imports strategy.

JEL classification: F14, F31, F47, F55.

Paper Type: Research study.

\footnotetext{
${ }^{1}$ Universitas Negeri Jakarta, email: indah_nikensari@unj.ac.id;

${ }^{2}$ Universitas Terbuka,email: nindyafarah@ecampus.ut.ac.id;

${ }^{3}$ Universitas Negeri Semarang, email: amin.pujiati@mail.unnes.ac.id;
} 


\section{Introduction}

The welfare of the whole community is the country's ultimate goal. One way to achieve prosperity is through economic growth, especially in poor and developing countries, but not for developed countries because people in developed countries are more concerned with the quality of their environment (Jackson, 2009). The same opinion expressed by Gray, Lobao and Martin (2012) who said that there is increasing dissatisfaction with economic growth as a leading indicator of prosperity in developed countries, because they prefer institutions to support their life quality. It was also said by Costanza et al. (2014) that GDP and growth are dangerous measures of quality of life. But in the ASEAN region, some countries are still in the category of developing stage, even some are still in the poor category, and only Singapore is above the category of developing countries, so economic growth in the region is still needed. The economic growth is needed to increase the production of goods and services in these countries for their people. For this reason, if capital goods to produce final domestic goods are not available in the country, then import is one way to overcome scarcity (Wang, Gao, Liu, and Hailu, 2014), both imports of raw materials and imports of capital goods used to produce final goods. Some other researchers also said that import activities were still needed to increase economic growth even through FDIs (Bakari and Mabrouki, 2017; Kahia, Aïssa, and Lanouar, 2017; Lee, 1995; Cieslik and Hiem Tran, 2019; Boehlke, Fałdzinski, Gałecki, and Osińska, 2020).

In recent years there has been a trend of global slowdown in economic growth, especially in the 2018-2019 period, where world import and export activity also slowed. The economic slowdown was triggered by the European crisis and the economic recovery of the United States after the financial crisis that occurred in 2008 (Koopman and Székely, 2009). According to the World Trade Organization, there was stagnation in world trade in 2011-2016, with an average growth of less than $3.0 \%$, although in 2017 it began to increase. As part of Asia, several countries in the ASEAN region also experienced the same trend, with negative import growth, especially in the 2014-2016 period, but import growth of all countries returned positive in 2017-2018 (Figure 1).

The decline in imports is good for the trade balance, but the problem is when the decline in imports is caused by the low ability of imports due to limited foreign exchange reserves. Because if imports decline, especially imports for capital goods, it can hamper the domestic production process. Conversely, if imports are too large and exceed the country's ability to pay for it, or flood the domestic market, then import policies and strategies are needed. Some policies and strategies such as market protection (Ederington and Minier, 2003), anti-dumping policies and import regulations (Bown and Tovar, 2011; Swann, 2018), restrictions on unnecessary import activities (Luedde-Neurath, 2019), certain strategies policy (Lake, 2018; Ossa, 2014) are needed, so they can secure the position of the trade balance while maintaining and increasing the rate of national economic growth. 
Figure 1. Imports growth in ASEAN (\%)

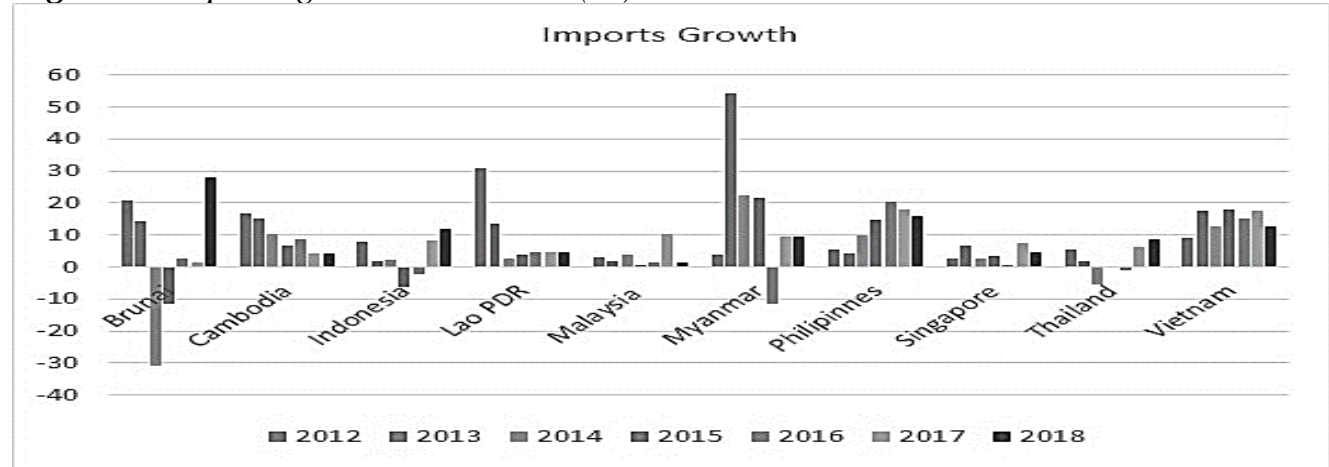

Source: World Trade Organization.

Studies on imports and influencing factors have been carried out, but import studies specifically comparing GDP and foreign exchange reserves, as well as policy strategies for imports are still rarely conducted. This study has two main objectives, the first to analyze which factors are more influential on falling imports in ASEAN countries, whether caused by the declined of GDP so that in the current year production also declined, or because of the limited availability of foreign exchange reserve, or because of other factors. The second objective is to propose an alternative import strategy related to the decline in imports at recent years, so that in the future it can improve economic growth and prosperity.

\section{Literature Review}

Import is the activity of entering goods through other countries' customs areas. Import transactions usually use an approved foreign currency payment instrument, so foreign exchange ownership determines import activities. Importing means buying foreign goods and services by citizens, companies and the government of a country. As mentioned earlier, imports of goods, including imports of capital goods, are good for the economy, because imports can overcome the scarcity of goods in the country and with a large population (Wang et al., 2014) can increase economic growth through imports of capital goods and international trade (Ghosh, 2009; Uğur, 2008). Therefore, the decline of imports in ASEAN countries needs to know the main cause, because ASEAN countries that are members of the AFTA (ASEAN Free Trade Area), have imposed zero tariffs on many items written on an inclusive list. So, if imports of a country decline, usually exports of other countries also decline, otherwise if exports decline, income on foreign exchange also declines.

Foreign exchange reserves are very important in import activities, because as mentioned above, import activities usually use approved foreign currency payment instruments, and most of them use US dollars (Kallianiotis, Bianchi, Arize, Malindretos, and Ndu, 2020). Countries with high foreign exchange reserves, in conditions of severe crisis, like the recent crisis, slightly decrease in economic 
growth, because they are still free to import capital goods for production purposes (Bussière, Cheng, Chinn, and Lisack, 2015). Conversely, foreign exchange reserves that are too high (foreign exchange reserves accumulation) have a static and dynamic impact; the static impact is that it can sacrifice domestic expenditure (because it is not used to import needed goods), so that it can reduce the level of welfare while the dynamic impact is that it can increase income from investment in the capital-intensive trading sector (Korinek and Serven, 2016).

\subsection{Factors Affecting Imports}

In general, there are several factors that can affect the volume of imports in some current trade areas. Aljebrin and Ibrahim (2012) state that import demand in the short and long term is affected by real income (GDP), public consumption, foreign exchange reserves, and gross capital formation on imports in the Arabian Gulf countries (GCC). Other studies, conducted by Abbas and Waheed (2018) concluded that imports in a country (Bahrain) were determined by the income of its trading partners, gross domestic product, export flows, relative prices and also the similarity of languages and regional economic integration. In addition, in the group of developing countries (emerging countries), imports are largely determined by the exchange rate (Genc and Artar, 2014).

Imports that are influenced by needs depend on the type of need, whether imports of capital goods, imports to meet scarcity (imports of staples), or imports of other tradable goods. A researcher from Indonesia states that the import of Indonesian compressor engines from China as capital goods is only influenced by GDP, while foreign exchange and inflation do not affect machine imports (Wiguna, 2014). Imports of basic necessities such as sugar in Indonesia are influenced by the import of sugar in the previous year, consumption of sugar and domestic sugar stock (Hairani, Aji, and Januar, 2014). Other researchers also stated that per capita income and foreign exchange reserves partially had a positive and significant effect on imports of motor vehicles in Indonesia in 1993-2013, while the rupiah exchange rate on the US dollar had no effect (Widanta and Indrawan, 2015). In the three groups of researchers above (imports of capital goods, imports of basic goods and imports of luxury goods), was concluded that imports of capital goods (compressor machines) were more influenced by domestic products of the importing country. This means that the higher the GDP of a country, the more imports of capital goods are required to increase subsequent GDP.

The same conclusion was stated by Adi (2017) that in the short and long term, GDP influences the import of goods in Indonesia, where Indonesia's largest imports are capital goods. As for the import of staple goods (sugar), is influenced by the needs of the population, while imports of non-staple goods (motorized vehicles) are more influenced by per capita income and foreign exchange owned by the state, not by the exchange rate. Based on some of the explanations above, the study tries to classify the factors that affect a country's imports as follows: 
Gross Domestic Product (GDP): GDP is a measure of national income, that can be calculated using current prices and constant prices. Constant price GDP is used to calculate a country's economic growth. If a country's economic growth increases, the demand or import of an item (especially capital goods) increases in the following year, which is used to maintain and / or increase subsequent economic growth, in other words economic growth in the current year is influenced by economic growth in the previous year. This is proven by research which states that imports in the short run are affected by income elasticity (Sinha, 1997), this means that if the income (GDP) of the previous year rises, then demand for the following year also rises. From the consumer side, the size and distribution of income of a country's population also affect import demand (Hummels and Lee, 2018). When one's income increases, the purchasing power increases, assuming that the price of the item remains fixed. In the macroeconomic context, people's income calculated using the production approach is reflected by gross domestic product (GDP). GDP is the overall value of final goods and services produced using the factors of production in a country in a certain period. It can also be calculated using the expenditure approach $(\mathrm{GDP}=\mathrm{C}+\mathrm{I}+\mathrm{G}+(\mathrm{X}-\mathrm{M}))$ and the income approach by adding up the remuneration for the factors of production. GDP also affects a country's imports both in the short and long term (Ayodotun and Farayibi, 2016; Özturk, 2012).

Foreign Exchange Reserves: Capital used for imports must be a foreign payment instrument in the form of foreign currencies in accordance with the import agreement, or what is called foreign exchange. Foreign exchange is a means of foreign payment in the form of gold, foreign bank notes and other bills in foreign currencies to foreign parties owned by the state. Foreign exchange own by the state is called foreign exchange reserves. Import transactions must use foreign payment instruments in the form of foreign currencies according to the agreement. When the level of foreign exchange reserves increases, it can affect import demand because more funds will be available for imports. Sultan (2011) said that in the long run, real imports in India are affected by real foreign exchange reserves, real income, and the relative prices of imports. The same research but in different regions was carried out by Arize and Malindretos (2012), stated that imports in India, Japan, Korea, Singapore and Thailand are affected by foreign exchange reserves, real income and relative import prices.

Inflation Rate: Inflation measures the increase in the average price of a group of goods in a certain period. Several factors can influence inflation, including the money supply (Nguyen, 2015). If the money supply increases, the price of domestic goods increases too; this increase causes demand for domestic goods to decline, which is then replaced by demand for imported goods. The inflation rate or the domestic price level has affected imports in Nigeria (Nteegah and Mansi, 2017), although according to Ihrig et al. (2010) imported goods affect domestic inflation.

Total Population: Residents are those who reside or domicile within the territory of a country. Demand for an item can be influenced by the population of an area 
(Porkka, Guillaume, Siebert, Schaphoff, and Kummu, 2017). In developing countries, import requests are influenced by per capita income and population (Faini, Pritchett, and Clavijo, 1992). There is an elastic relationship both short-term and long-term between population growth and import demand in Brunei Darusalam (Narayan and Smyth, 2005). In other words, if the population is large or increases, usually the demand for an item is relatively large / increased. However, if the amount of goods in the country that is available is not balanced with the population in the area, it would happen scarcity of goods. The large population is also a market for goods from abroad, so that the type of imported goods is not only capital goods and basic needs, but also other primary, secondary, and tertiary goods.

The above are several factors that affect the demand for imported goods. But the problem is when the available foreign exchange reserves continue to decline, the need for capital goods and basic goods necessities is urgent. For this reason, several strategies are implemented to overcome these problems.

\subsection{Some Strategies of Imports}

Trade strategy is a government plan or method for obtaining one or more objectives within the international economy related to the import or export of tangible goods (Lake, 2018). According to Lake, there are two dimensions in trading strategies (Table 1), the first is an international market-oriented strategy, and the second dimension is the degree of policy on international trade activities.

Table 1. The dimensions and indicators of trade strategy

\begin{tabular}{|c|c|c|c|}
\hline \multirow{2}{*}{$\begin{array}{l}\text { International } \\
\text { Market } \\
\text { Orientation }\end{array}$} & Liberal & $\begin{array}{l}\text { - low } \\
\text { - non-negotiable } \\
\text { - non-discriminatory tariffs }\end{array}$ & $\begin{array}{l}\text { - low } \\
\text { - negotiable } \\
\text { - non-discriminatory tariffs }\end{array}$ \\
\hline & Protectionist & $\begin{array}{l}\text { - hight } \\
\text { - nonnegotiable } \\
\text { - discriminatory tariffs }\end{array}$ & $\begin{array}{l}\text { - high } \\
\text { - negotiable } \\
\text { - discriminatory tariffs }\end{array}$ \\
\hline & & Passive & Active \\
\hline & & \multicolumn{2}{|c|}{ Degree of international political activity } \\
\hline
\end{tabular}

Source: Lake, 2018.

The first dimension refers to the country's willingness to permit the international market to control its trade flow, which consists of a liberal / open / free trade strategy, and a protectionist or mercantilist trading strategy, which among others uses tariffs, non-barriers to trade, barter arrangemnets or centrally planned trade. The second dimension of trading strategy consists of passive strategies and active strategies; passive strategies are usually related to policies directed at the domestic economy of the country itself, while active strategies are usually related to efforts to influence the economic order and policies of other countries. 
Ossa (2014) also proposes cooperative and non-cooperative policy strategies to tackle trade wars. Cooperative policy strategy by conducting inefficient trade negotiations, both through tariffs and non-tariffs that will produce significant prosperity. Non-cooperative policy strategies can also be through unilateral tariffs. Suranovic (2010) explains the protection policy in international trade. According to him, there are two categories of protection policies, namely trade policies that increase domestic national welfare but at the same time reduce aggregate world welfare, and trade policies that not only increase domestic welfare but also increase world welfare.

Since before 2000 until now, the US has always been deficit in trade. One way to overcome this problem is to implement a trade strategy like the US has done recently, especially in the trade war with China and several other countries, to reduce the invasion of imports and increase foreign trade. The impact of this strategy, throughout 2019, the U.S. experienced substantial increases in the prices of intermediates goods and final goods, dramatic changes to its supply-chain network, reductions in availability of imported varieties, and complete passthrough of the tariffs into domestic prices of imported goods (Amiti, Redding, and Weinstein, 2019). The US has implemented some of trading strategies not only lately, but several times before.

Observing the current global conditions in which a trade war is fought between the United States and China, the US imposes high tariffs on goods from China, and no longer seems to be following the liberal international market orientation. Some goods imported from China at this time are indeed still there that have not been subject to high tariffs, especially for hardware goods, so that US strategies and policies can be said to be protective. Protective policies themselves will benefit the country.

In the spirit of cooperation among regional countries, the ASEAN regional trade has been supported through the maintenance of open market policies, infrastructure improvements, and technological advances (ASEAN Regional Report 2019). But the current account balance until 2018 shows an increase in vulnerability to external factors, and trade tensions between the US and China in 2018 affected several ASEAN countries. Cooperation between ASEAN countries needs to be strengthened, and must be selective in importing goods from outside ASEAN. Some free trade cooperation agreements in the region that can be used as import strategies include:

Protocol Regarding the Implementation of the CEPT scheme Temporary Exclusion List. This scheme is to revoke industrial products that have been included in the inclusive list (deadline in 2000).

Article 6 (1) of the CEPT Agreement. This scheme is used to recall products that have been listed on an inclusive list, due to a surge in imports in the 
countries of the region which has caused serious losses to the domestic industry.

Protocol on Special Arrangement for Sensitive and Highly Sensitive Products. This scheme used as a reference to include products such as rice and sugar for countries that lack these two commodities.

\section{Research Methods}

Based on the phenomenon of the factors that influence the above, there are several factors that affect a country's imports, such as GDP (the higher the GDP, the greater imports, especially imports of capital goods for community needs for this year), the ability of foreign exchange reserves (ability to pay for imports), domestic inflation (affecting domestic prices), and population (related to import needs to meet scarcity). This study uses secondary data, from all countries in the Southeast Asian region (10 countries), in a period of 7 years, 2012-2018. Sources of data were obtained from various official sources, namely the World Bank, World Trade Organization (WTO), and other official sites.

The analysis in this study uses multiple linear regression panel data, which is a regression analysis used to estimate the value of the dependent variable that is influenced by several independent variables. The steps taken include descriptive statistical analysis, test requirements analysis, selection of the best regression model, hypothesis testing, and analysis of research results. The general regression equation used is:

Where:

$$
\mathrm{IM}_{\mathrm{it}}=\alpha+\beta_{1} \mathrm{IGDP}_{\mathrm{it}}+b_{2} \mathrm{IFER}_{\mathrm{it}}+b_{3} \mathrm{Ifl}_{\mathrm{it}}+b_{4} \mathrm{IPop}_{\mathrm{it}}+\varepsilon_{\mathrm{it}}
$$

$\mathrm{IM}_{\mathrm{it}}$

: Demand of import $\mathrm{i}$ in year $\mathrm{t}$ ( $\$$ millions)

$\operatorname{lnGDP}{ }_{i t}$

: Gross Domestic Product i in year $\mathrm{t}$ (\$ millions)

$\operatorname{lnFER}_{\mathrm{i}}$

: Foreign exchange reserves $\mathrm{i}$ in year $\mathrm{t}$ ( $\$$ millions)

Infl $_{\text {it }}$

: Inflation rate $\mathrm{i}$ in year $\mathrm{t}(\%)$

$\ln$ opop $_{\text {it }}$

: Total Population i in year $\mathrm{t}$ (millions)

For the general equation above, several tests were conducted to choose whether Pool Least Square (PLS), Ordinary Least Square (OLS), or GLS (General Least Square) is the most appropriate model to be used. Chow tests and Hausman tests are performed to select the best equation model, fixed effect model (FEM), random effect model (REM) or Pooled Least Squares (PLS) / Common Effect (CEM) model. FEM and PLS / CEM use the Ordinary Least Squared (OLS) approach, while the Random effect uses Generalized Least Squares (GLS). Furthermore, to test the hypothesis t-test and F-test have been used. These hypothesis tests are needed to test whether the regression coefficients are significant, independently or simultanesly. Furthermore, the analysis of the coefficient of determination (Goodness of fit) is also performed, to measure the ability of the model to explain the variation of the dependent variable caused by the independent variables. 


\section{Results and Discussion}

The following is the description of the variables used in this research in Southeast Asian countries, consisting by 10 countries in the period 2012-2018. Figure 2 illustrates the imports' growth of ASEAN countries. It appears that Singapore is a country with the highest average imports, followed by Thailand, Malaysia, Indonesia, Vieinam, and Thailand, while the average imports of four other countries such as Myanmar, Cambodia, Brunei and Lao PDR are lower. Meanwhile, a description of the factors influencing import demand in this study is presented below.

\section{Imports:}

The mean value of imports is 118,620 (in millions) and the standard deviation is 114,060 (in millions). If the two values are compared, the mean value of imports is greater than the standard deviation value, so it can be concluded that the mean value of imports can present the average value of imports as well. Singapore is the country with the highest average imports, while the lowest import value is in Laos. The movement of imports in the countries of Southeast Asia experienced ups and downs as the global economic turmoil was not yet stable after the monetary crisis in 2008 .

\section{Figure 2. Imports in ASEAN}

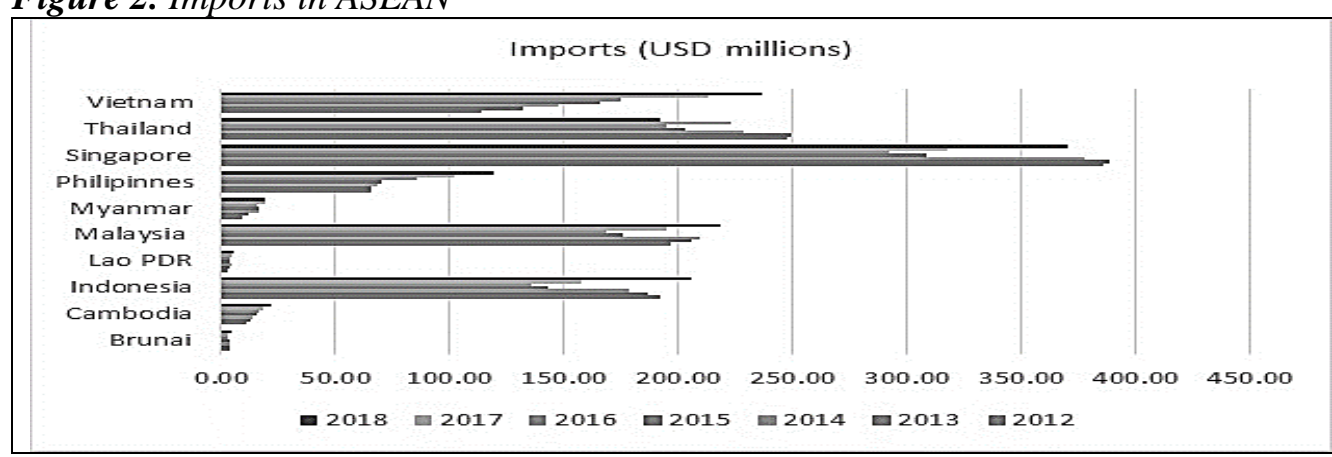

Source: Own study.

\section{Gross Domestic Product:}

In this study, the value of GDP is measured by Gross Domestic Product at current prices. This GDP data is nominal, measured in units of US\$. The average value of GDP variable data is 250,846 (in millions) and the standard deviation value is 264,229 (in millions). If the two values are compared, the mean value of GDP is smaller than the standard deviation value, so it can be concluded that the mean value of GDP cannot properly represent the average value of GDP data. The country with the highest GDP is Indonesia, while Laos has the lowest GDP. As can be seen in Figure 2, the movement of GDP in countries in the Southeast Asian region is heading for an upward trend. 


\section{Inflation:}

The inflation referred in this study is the year-to-year inflation rate calculated from the Consumer Price Index (CPI). At the ASEAN level, the mean inflation is $3.29 \%$ and the standard deviation is $3.02 \%$. From the results of these calculations, the mean inflation value is greater than the standard deviation value, so it can be concluded that the mean inflation can present the data properly. The highest inflation occurred in Vietnam, while the lowest inflation value is in Thailand. Inflation rates in almost all countries tend to decrease, although there is also an increase in certain years.

\section{Foreign Exchange Reserves (FER):}

The foreign exchange reserves in this study represent the availability of foreign currencies, gold and securities managed by the monetary authority. Foreign exchange reserves are measured in units of currency value of US \$ (current). The mean of foreign exchange reserves in ASEAN is 79,305 (in millions) and the standard deviation value is 84,644 (in millions). If compared, the mean GDP is smaller than the standard deviation, so it can be concluded that the average value of foreign exchange reserves does not represent the average value of foreign exchange reserves well. Singapore has the highest foreign exchange reserves, while Laos has the smallest foreign exchange reserves. Fluctuations in the value of foreign exchange reserves occur in almost all countries except Cambodia, which showed an increasing trend throughout 2011-2017.

\section{Population:}

The population is the number of people who live and are recorded as citizens in the country concerned. Data on population is in the form of nominal figures. The mean value of the population is 62 (in millions) and the standard deviation is 72 (in millions). When compared to these two values, the average value of the total population is smaller than the standard deviation value, so it can be concluded that the average value of the population number cannot present the average value of the data from the variable population size well. The highest population is in Indonesia, while the lowest population is in Brunei. The population in ASEAN countries continues to increase significantly each year.

Based on the t-test, all independent variables (GDP, FER, Inflation, Population) partially have an influence on import demand in ASEAN countries, with different significance levels. While simultaneously all independent variables significantly influence import demand. The result also shows that import demand is negative or near zero if not influenced by other variables. GDP, FER, and inflation have a positive effect, while the population has a negative effect. This means that if GDP, FER, and inflation increase, imports will rise, so import demand will be positive, and no longer negative. Meanwhile, if the population rises, and other variables approach zero, imports will decline. The reason is that imports are strongly influenced by other variables related to the main drivers of economic growth and availability of payments, which in this study are represented by the variables GDP and FER. 
Based on the elasticity coefficient of the lin-log regression equation, GDP has the greatest influence on import demand, followed by FER, and Inflation. Thus, two variables, GDP and Foreign Exchange Reserves (FER) greatly affect import demand in ASEAN countries. These results are consistent with the hypothesis proposed that GDP and FER have a positive effect on imports. The results of this study reinforce the theory that GDP was the basis for importing capital goods, and foreign exchange reserves reflected whether a country could finance imports or not. In this equation, import demand is represented by the value of imports (US\$ million), while the independent variables are the result of natural logarithms.

Table 2. Hypothesis test for imports with REM equation

\begin{tabular}{|ll|ll|}
\hline Independend var. & Coef. & T-stat \\
\hline Constant a & $\mathrm{t}_{\text {stat }}$ & $-106.77^{* *}$ & $(-1.810)$ \\
\hline LGDP & $\mathrm{t}_{\text {stat }}$ & $41.593^{* * *}$ & $(2.081)$ \\
\hline Ln FER & $\mathrm{t}_{\text {stat }}$ & $34.592^{* * *}$ & $(2.588)$ \\
\hline $\mathrm{Inf}$ & $\mathrm{t}_{\text {stat }}$ & $3.176^{* * *}$ & $(2.080)$ \\
\hline Ln Pop $\quad \mathrm{t}_{\text {stat }}$ & $-29.509^{* * *}$ & $(-2.147)$ \\
\hline $\mathrm{F}_{\text {stat }}$ & $(9.379)$ & \\
\hline $\mathrm{R}^{2}$ & 0.8030 & \\
\hline
\end{tabular}

Note: $* * *, * *$, significant at $1 \%$ and $5 \%$ level.

Source: Own study.

The results of this study strengthen the theory that increasing GDP is the basis for importing capital goods, and foreign exchange reserves are reflected on whether a country can finance imports or not. This is because industries in developing countries require the supply of high-tech raw materials and capital goods from developed countries, such as factory machinery, automotive parts, pharmaceutical basic materials, and others, which are still short in developing countries. The limitations of developing countries in creating and producing capital goods cause increased imports of capital goods. If GDP increased, or in other words the productivity of developing countries increased, then in the following year the developing countries increased purchases of capital goods from abroad so that there would be sustainable production.

The problem is that there are limited foreign exchange reserves as state assets used for international transactions, because foreign reserves are not only a tool for payment of import transactions, but also are used to pay debts and installments. World trade with a slowing trend from 2011 until 2016, increasing in 2017 and decreasing in 2018, has an impact on declining income from exports, thereby reducing foreign exchange reserves.

Based on the findings and the discussion above, we would like to offer a model of import policy strategies that can be used to reduce or increase imports, as shown in Table 3. 
This import policy strategy is simple and flexible to be implemented in any country in the ASEAN region, namely a protective strategy and a non protective strategy. The protective strategy is carried out by the state to protect domestic interests, for example floods of imported goods that threaten domestic production, and it also potentially reduce the country's foreign exchange reserves. This strategy can be done through negotiation or renegotiation, or it can be done unilaterally if import expansion is a serious threat. But protection strategies not only limit imports, but also increase imports related to domestic needs such as economic growth, defense and security, culture, etc. Conversely, in a non-protective strategy, countries are free to increase imports or reduce imports, both by agreement and without agreement.

Table 3. International imports strategy

\begin{tabular}{|l|c|c|c|}
\hline & \multicolumn{2}{|c|}{ Protective strategy } & Non protective strategy \\
\hline Co-operative & negotiation & renegotiation & Free trade by agreement \\
\hline Non cooperative & \multicolumn{2}{|c|}{ unilateral decision } & Free trade without agreement \\
\hline Types of strategies & \multicolumn{2}{|c|}{ Tariff, quota, policy } & Policy \\
\hline
\end{tabular}

Source: Own study.

With regard to the case of imports in ASEAN where foreign exchange reserves (FER) have a greater significance than GDP, then if imports continue to rise sharply but exports decline / remain, then protection strategies must be implemented, as is the case in the United States. Conversely, if imports decline sharply after previous imports are always high as in Myanmar, then a protective policy strategy to increase imports must also be carried out immediately, so that economic growth is not hampered. On the other hand, if import growth is stable, a non-protective strategy might be possible. If the protection strategy is applied unilaterally for goods that usually originate from countries outside the ASEAN region, then this is classified as a non-cooperative protection strategy.

But protective strategies can also be applied in ASEAN region, because there are agreements governing them. CEPT (Common Effective Preferential Tariff) Agreement is one of them, used as a reference to recall traded products that were previously included in the AFTA CEPT scheme. This facility is used if there is a surge in imports from ASEAN member countries that cause or threaten serious losses to the domestic industry. CEPT aggrement includes a protection strategy through renegotiation cooperation.

The above strategy certainly deviates from the free trade agreements initiated by the World Trade Organization in the beginning and has been implemented in many countries and trade regions. But free trade agreements should not harm their own country, and only benefit their trading partners. In addition, in free trade agreements there are still loopholes in renegotiations that will benefit both parties. 
In addition, there are other ways to overcome the problem of increased imports related to foreign exchange ownership limitations, namely by inviting foreign investors to produce import replacement products. This possibility is wide open, especially with conditions where the US is waging a trade war with China, which has stopped the supply of components of capital goods from China. As a result of US trade policy, US companies have an interest in finding suppliers / partners in new locations outside China, which have profitable growth ecosystems, including countries in the ASEAN region. The positive impact of the trade war between the US and China is to seize the market opportunities left by both the US and China for countries not involved in this trade war. Some goods that cannot be imported from the two countries can be supplied by other countries, including countries in the ASEAN region.

\section{Conclusion and Recommendations}

Based on the explanation above, it can be concluded that the amount of foreign exchange reserves and Gross Domestic Product (GDP) are very influential on current import demand, while the population and inflation rate have a lower influence. The significant influence of foreign exchange reserves and GDP required policy makers to implement strategies to increase foreign exchange reserves used for imports, amidst a stagnant world trade situation.

During the research period, in line with the slowing trend in world trade, where export activity declined which impacted on the decline in foreign exchange reserves, a protection strategy related to import demand needs to be implemented so that economic growth does not decline. Because, if GDP goes down, import demand for capital goods will fall, which in turn will have an impact on declining economic growth. Likewise, if foreign exchange reserves decrease, can have an impact on the decline in import demand. For this reason, the application of a protection strategy related to import demand needs to be carried out.

Limited foreign exchange reserves due to declining export activities that have an impact on the decline in imports of capital goods, among others, can be avoided by re-selecting the list of goods to be imported. In other words, foreign exchange reserves are only used for urgent foreign payments, such as the purchase / import of capital goods. If imports of capital goods continue, productivity will increase, and GDP or economic growth will also increase, which in turn will increase imports.

\section{References:}

Abbas, S., Waheed, A. 2018. Import Determinants and Potential Markets: A Panel Data Gravity Modelling Analysis for Bahrain. Review of Middle East Economics and Finance, 14(1).

Adi, L. 2017. Effect of Exchange Rate and GDP on Indonesian Exports and Imports. Develop, 1(1). Doi: https://dx.doi.org/10.25139/dev.v1i1.69. 
Aljebrin, M.A., Ibrahim, M.A. 2012. The determinants of the demand for imports in GCC countries. International Journal of Economics and Finance, 4(3), 126-138.

Arize, A.C., Malindretos, J. 2012. Foreign exchange reserves in Asia and its impact on import demand. International Journal of Economics and Finance, 4(3), 21-32.

Ayodotun, A., Farayibi, A. 2016. Modelling the determinants of import demand in SubSahara Africa. Available at SSRN 2828351.

Bakari, S., Mabrouki, M. 2017. Impact of exports and imports on economic growth: new evidence from Panama. Journal of Smart Economic Growth, 2(1), 67-79.

Boehlke, J., Fałdzinski, M., Gałecki, M., Osińska. M. 2020. Searching for Factors of Accelerated Economic Growth: The Case of Ireland and Turkey. European Research Studies Journal, 23(1), 292-304. DOI: 10.35808/ersj/1550.

Bown, C.P., Tovar, P. 2011. Trade liberalization, antidumping, and safeguards: evidence from India's tariff reform. Journal of development economics, 96(1), 115-125.

Bussière, M., Cheng, G., Chinn, M.D., Lisack, N. 2015. For a few dollars more: Reserves and growth in times of crises. Journal of International Money and Finance, 52, 127145.

Cieślik, A., Hien Tran, G. 2019. Determinants of outward FDI from emerging economies. Equilibrium. Quarterly Journal of Economics and Economic Policy, 14(2), 209-231. doi: 10.24136/eq.2019.010.

Costanza, R., Kubiszewski, I., Giovannini, E., Lovins, H., McGlade, J., Pickett, K.E., Wilkinson, R. 2014. Development: Time to leave GDP behind. Nature News, 505(7483), 283.

Ederington, J., Minier, J. 2003. Is environmental policy a secondary trade barrier? An empirical analysis. Canadian Journal of Economics/Revue canadienne d'économique, 36(1), 137-154.

Faini, R., Pritchett, L., Clavijo, F. 1992. Import demand in developing. International trade modelling, 279.

Genc, E.G., Artar, O.K. 2014. The effect of exchange rates on exports and imports of emerging countries. European Scientific Journal, 10(13).

Ghosh, S. 2009. Import demand of crude oil and economic growth: Evidence from India. Energy Policy, 37(2), 699-702.

Gray, M., Lobao, L., Martin, R. 2012. Making space for well-being. Cambridge Journal of Regions, Economy and Society, 5(1), 3-13.

Hairani, R.I., Aji, J.M.M., Januar, J. 2014. Analisis Trend Produksi dan Impor Gula Serta Faktor-Faktor yang Mempengaruhi Impor Gula Indonesia. Berkala Ilmiah Pertanian, 1(4), 77-85.

Hummels, D., Lee, K.Y. 2018. The income elasticity of import demand: Micro evidence and an application. Journal of international Economics, 113, 20-34.

Ihrig, J., Kamin, S.B., Lindner, D., Marquez, J. 2010. Some simple tests of the globalization and inflation hypothesis. International Finance, 13(3), 343-375.

Jackson, T. 2009. Prosperity without growth: Economics for a finite planet (1th ed.). London: Routledge.

Kahia, M., Aïssa, M.S.B., Lanouar, C. 2017. Renewable and non-renewable energy useeconomic growth nexus: The case of MENA Net Oil Importing Countries. Renewable and Sustainable Energy Reviews, 71, 127-140.

Kallianiotis, N.I., Bianchi, K., Arize, C.A., Malindretos, J., Ndu, I. 2020. Financial Assets, Expected Return and Risk, Speculation, Uncertainty, and Exchange Rate Determination. European Research Studies Journal, 23(3), 3-30. DOI: $10.35808 / \mathrm{ersj} / 1622$. 
Koopman, G., Székely, I. 2009. Impact of the current economic and financial crisis on potential output. European Economy, Occasional Paper, (49).

Korinek, A., Serven, L. 2016. Undervaluation through foreign reserve accumulation: Static losses, dynamic gains. Journal of International Money and Finance, 64, 104-136.

Lake, D.A. 2018. Power, protection, and free trade: International sources of US commercial strategy, 1887-1939. Cornell University Press.

Lee, J.W. 1995. Capital goods imports and long-run growth. Journal of development economics, 48(1), 91-110.

Luedde-Neurath, R. 2019. Import controls and export-oriented development: A reassessment of the South Korean case. Routledge.

Narayan, P.K., Smyth, R. 2005. The determinants of aggregate import demand in Brunei Darussalam: an empirical assessment using a cointegration and error correction approach. The Singapore Economic Review, 50(02), 197-210.

Nguyen, B. 2015. Effects of fiscal deficit and money M2 supply on inflation: Evidence from selected economies of Asia. Journal of Economics, Finance and Administrative Science, 20, 49-53.

Nteegah, A., Mansi, N. 2017. Analysis of factors influencing import demand in Nigeria. West African Journal of Industrial and Academic Research, 17(1), 88-100.

Ossa, R. 2014. Trade wars and trade talks with data. American Economic Review, 104(12), 4104-4146.

Öztürk, M. 2012. Macroeconomic factors affecting the import in Turkey. Journal of QafQaz University, 34(2012), 39-46.

Porkka, M., Guillaume, J.H., Siebert, S., Schaphoff, S., Kummu, M. 2017. The use of food imports to overcome local limits to growth. Earth's Future, 5(4), 393-407.

Sinha, D. 1997. Determinants of import demand in Thailand. International Economic Journal, 11(4), 73-87.

Sultan, Z.A. 2011. Foreign exchange reserves and India's import demand: A cointegration and vector error correction analysis. International Journal of Business and Management, 6(7), 69.

Suranovic, S. 2010. International Economics: Theory and Policy. Boston, FtatWorld.

Swann, D. 2018. Competition and industrial policy in the European Community. Routledge.

Uğur, A. 2008. Import and economic growth in Turkey: Evidence from multivariate VAR analysis. Journal of economics and Business, 11(1-2), 54-75.

Wang, W., Gao, L., Liu, P., Hailu, A. 2014. Relationships between regional economic sectors and water use in a water-scarce area in China: a quantitative analysis. Journal of hydrology, 515, 180-190.

Widanta, A.B.P., Indrawan, I.W.A. 2015. Effects of US Dollar Exchange Rate, Per capita Income, and Foreign Exchange Reserves on the Import Value of Motorized Vehicles in Indonesia. E-Journal of Development Economics, Udayana University, 4(5), 499-512.

Wiguna, I.B.W.S. 2014. The Influence of Foreign Exchange, US Dollar Exchange Rate, GDP and Inflation Against Imports of Compressor Machines From China. Journal of Development Economics Edayana University, 3(5), 173-181. 